\title{
PUBLICATION ETHICS AND MALPRACTICE STATEMENT
}

Jurnal Inovasi Pendidikan IPA is a peer-reviewed electronic international journal. This statement clarifies ethical behaviour of all parties involved in the act of publishing an article in this journal, including the author, the chief editor, the Editorial Board, the peer-reviewer and the publisher (Universitas Negeri Yogyakarta). This statement is based on COPE's Best Practice Guidelines for Journal Editors.

\section{Ethical Guideline for Journal Publication}

The publication of an article in a peer-reviewed of Jurnal Inovasi Pendidikan IPA is an essential building block in the development of a coherent and respected network of knowledge. It is a direct reflection of the quality of the work of the authors and the institutions that support them. Peer-reviewed articles support and embody the scientific method. It is therefore important to agree upon standards of expected ethical behavior for all parties involved in the act of publishing: the author, the journal editor, the peer reviewer, the publisher and the society.

Universitas Negeri Yogyakarta as publisher of Jurnal Inovasi Pendidikan IPA takes its duties of guardianship over all stages of publishing extremely seriously and we recognize our ethical and other responsibilities. We are committed to ensuring that advertising, reprint or other commercial revenue has no impact or influence on editorial decisions. In addition, the Graduate School Program of Universitas Negeri Yogyakarta and Editorial Board will assist in communications with other journals and/or publishers where this is useful and necessary.

\section{Publication Decisions}

The editor of the Jurnal Inovasi Pendidikan IPA is responsible for deciding which of the articles submitted to the journal should be published. The validation of the work in question and its importance to researchers and readers must always drive such decisions. The editors may be guided by the policies of the journal's editorial board and constrained by such legal requirements as shall then be in force regarding libel, copyright infringement and plagiarism. The editors may confer with other editors or reviewers in making this decision.

\section{Fair play}

An editor at any time evaluate manuscripts for their intellectual content without regard to race, gender, sexual orientation, religious belief, ethnic origin, citizenship, or political philosophy of the authors.

\section{Confidentiality}

The editor and any editorial staff must not disclose any information about a submitted manuscript to anyone other than the corresponding author, reviewers, potential reviewers, other editorial advisers, and the publisher, as appropriate.

\section{Disclosure and Conflicts of Interest}

Unpublished materials disclosed in a submitted manuscript must not be used in an editor's own research without the express written consent of the author.

\section{Duties of Reviewers}

\section{Contribution to Editorial Decisions}

Peer review assists the editor in making editorial decisions and through the editorial communications with the author may also assist the author in improving the paper.

\section{Promptness}

Any selected referee who feels unqualified to review the research reported in a manuscript or knows that its prompt review will be impossible should notify the editor and excuse himself from the review process.

\section{Confidentiality}

Any manuscripts received for review must be treated as confidential documents. They must not be shown to or discussed with others except as authorized by the editor.

\section{Standards of Objectivity}

Reviews should be conducted objectively. Personal criticism of the author is inappropriate. Referees should express their views clearly with supporting arguments.

\section{Acknowledgement of Sources}

Reviewers should identify relevant published work that has not been cited by the authors. Any statement that an observation, derivation, or argument had been previously reported should be accompanied by the relevant citation. A reviewer should also call to the editor's attention any substantial similarity or overlap between the manuscript under consideration and any other published paper of which they have personal knowledge. 


\section{Jurnal Inovasi Pendidikan IPA, 2 (2), 2016 - iv}

\section{Disclosure and Conflict of Interest}

Privileged information or ideas obtained through peer review must be kept confidential and not used for personal advantage. Reviewers should not consider manuscripts in which they have conflicts of interest resulting from competitive, collaborative, or other relationships or connections with any of the authors, companies, or institutions connected to the papers.

\section{Duties of Authors}

Reporting standards

Authors of reports of original research should present an accurate account of the work performed as well as an objective discussion of its significance. Underlying data should be represented accurately in the paper. A paper should contain sufficient detail and references to permit others to replicate the work. Fraudulent or knowingly inaccurate statements constitute unethical behaviour and are unacceptable.

\section{Data Access and Retention}

Authors are asked to provide the raw data in connection with a paper for editorial review, and should be prepared to provide public access to such data (consistent with the ALPSP-STM Statement on Data and Databases), if practicable, and should in any event be prepared to retain such data for a reasonable time after publication.

Originality and Plagiarism

The authors should ensure that they have written entirely original works, and if the authors have used the work and/or words of others that this has been appropriately cited or quoted.

\section{Multiple, Redundant or Concurrent Publication}

An author should not in general publish manuscripts describing essentially the same research in more than one journal or primary publication. Submitting the same manuscript to more than one journal concurrently constitutes unethical publishing behaviour and is unacceptable.

\section{Acknowledgement of Sources}

Proper acknowledgment of the work of others must always be given. Authors should cite publications that have been influential in determining the nature of the reported work.

\section{Authorship of the Paper}

Authorship should be limited to those who have made a significant contribution to the conception, design, execution, or interpretation of the reported study. All those who have made significant contributions should be listed as co-authors. Where there are others who have participated in certain substantive aspects of the research project, they should be acknowledged or listed as contributors. The corresponding author should ensure that all appropriate co-authors and no inappropriate co-authors are included on the paper, and that all co-authors have seen and approved the final version of the paper and have agreed to its submission for publication.

\section{Hazards and Human or Animal Subjects}

If the work involves chemicals, procedures or equipment that have any unusual hazards inherent in their use, the author must clearly identify these in the manuscript.

Disclosure and Conflicts of Interest

All authors should disclose in their manuscript any financial or other substantive conflict of interest that might be construed to influence the results or interpretation of their manuscript. All sources of financial support for the project should be disclosed.

\section{Fundamental errors in published works}

When an author discovers a significant error or inaccuracy in his/her own published work, it is the author's obligation to promptly notify the journal editor or publisher and cooperate with the editor to retract or correct the paper. 
Available online at: http://journal.uny.ac.id/index.php/jipi

Jurnal Inovasi Pendidikan IPA, 2 (2), 2016, v

\section{ACKNOWLEDGMENT TO REVIEWERS IN THIS ISSUE}

Contribution from the following Reviewers in this issue was very appreciated for their valuable review comments:

Zuhdan Kun Prasetyo (Universitas Negeri Yogyakarta, Indonesia)

Eli Rohaeti (Universitas Negeri Yogyakarta, Indonesia)

Anna Permanasari (Universitas Pendidikan Indonesia, Indonesia)

D. Djukri (Universitas Negeri Yogyakarta, Indonesia)

Insih Wilujeng (Universitas Negeri Yogyakarta, Indonesia)

Rio Christy Handziko(Universitas Negeri Yogyakarta, Indonesia) 


\title{
Petunjuk Penulisan Naskah Jurnal Inovasi Pendidikan IPA (Versi Template 2016) $\leftarrow 13$ TNR Bold Maksimal 14 Kata
}

\author{
S. Senam ${ }^{1} *$, Zuhdan Kun Prasetyo ${ }^{2} \leftarrow 11$ pt bold \\ ${ }^{12}$ Department of Science Education, Universitas Negeri Yogyakarta. Colombo Street No. 1, \\ Karangmalang, Yogyakarta 55281, Indonesia. \\ * Coressponding Author. E-mail: senamkardiwiyono@yahoo.com
}

\begin{abstract}
Abstrak
Abstrak berbahasa Indonesia ditulis menggunakan TNR-11. Jarak antarbaris 1 spasi. Abstrak berisi 150-200 kata dan hanya terdiri atas 1 paragraf, yang memuat tujuan, metode, serta hasil penelitian.
\end{abstract}

Kata Kunci: 1 atau lebih kata atau frase yang penting, spesifik, atau representatif bagi artikel ini

\section{Instructions for Preparing Manuscript for Jurnal Inovasi Pendidikan IPA (2016 Template Version) $\leftarrow 13$ TNR Bold Italic 14 Words}

\begin{abstract}
Abstract english version, written using Time New Roman-11, italic. Abstract contains research aim/purpose, method, and reseach results; written in 1 paragraph, single space among rows, using past tense sentences.
\end{abstract}

Keywords: one or more word(s) or phrase(s), that it's important, specific, or representative for the article.

\section{INTRODUCTION}

This section contains the background of the study, the rationale and/or the urgency of the study. References (literatures and relevant studies) should be stated in relation to the justification toward the urgency of the study, the occurrence of the problem in the study, the alternative solutions and the selected solutions. The manner of stating the sources in the text must show the name of the author and the source citation clearly, which refers to the year of issuance or publication and the page where the related texts exist. For example: ... The results of the study showed that more than $70 \%$ of the students had not been able to recognize the authentic problems ... (Retnawati, 2014, p.6).

The degree of advancement within the materials that have been the reference should be given attention by viewing the proportion of the last 10 years and by looking at the primary literature. The problems, the objectives and the benefits of the study should be typed narratively in the form of paragraphs and the researcher does not need to provide any special subsections. Similarly, the operational definition might be typed narratively if it is deemed necessary.

The sub-title Introduction should be typed in TNR-11 straight with single space. Each paragraph should be started with the word that is indented inward 5 digits or around $1 \mathrm{~cm}$ from the left side of each column.

\section{METHOD}

This section contains the type, the period, the location, the target, the subject, the procedures, the instruments and the data analysis technique of the study along with the other matters that have been related to the manners of the study. These contents might be typed into the subtitles with the subheadings. The subtitles do not need to be provided with notation. However, the subtitles should be typed with the small case beginning with a capitalized letter, TNR-11 un-bold and left level.

Especially for the qualitative study, the period and the location of the study should be stated clearly (as well as for the quantitative study). The target/subject of the study (for the qualitative study) or the population-sample (for 
the quantitative study) should be elaborated clearly in the section. The researcher should also write the subject selection technique (for the qualitative study) and/or the sampling technique (for the quantitative study).

The procedures should be elaborated in accordance to the type of the study. In addition, the researcher should also elaborate how the study was conducted and how the data had been attained.

For the experimental study, the type of experimental design that had been implemented should be written in this section. The type of the data, how the data had been gathered, which instrument that had been used in gathering the data and the technique that had been used in gathering the data should be elaborated clearly as well in this section.

Furthermore, the meaning of the data and the connection between the data, the problems of the study and the objectives of the study should be elaborated in this section.

(Note: The subtitles might be different according to the type or the approach of the study that had been implemented. If there were sequential steps or procedures then the steps or the procedures might be provided with the notation (number or letter) according to the position.)

\section{RESULTS AND DISCUSSIONS}

The results of the study should be presented in the form of graphic, table or descriptive explanation. The analysis and the interpretation toward these results are necessary before starting the discussion.
The table should be written in the middle or in the end of each descriptive text discussing the results/findings of the study. If the width of the table is not sufficient to be written in the half page, then the table might be written in the full page. The title of the table should be written from the left to the center and all of the words should be started with the capital letter except for the conjunctions. If the title consists of more than one line, then the title might be written completely in the single space. The example for this explanation might be seen in Table 1 .

Table 1. The Style and Its Function

\begin{tabular}{rll}
\hline No. & \multicolumn{1}{c}{ Name of Style } & \multicolumn{1}{c}{ Function } \\
\hline 1. & JIPI_Title & Title \\
2. & JIPI_Author & Author \\
3. & JIPI_AbstractBody & Abstract \\
4. & JIPI_AbstractTitle & Abstract Title \\
5. & JIPI_AbstractKeyword & Keyword \\
6. & JIPI_Heading 1 & Subtitle 1 \\
7. & JIPI_Body & Paragraph \\
8. & JIPI_Picture Capture & Figure Title \\
9. & JIPI_Table Capture & Table Title \\
10. & JIPI_Reference & List of References \\
& And more & \\
\hline
\end{tabular}

The elaboration of the results that take the form of figure or the data that have been explained by means of figure/scheme/graphic/ diagram and alike should pay attention to the existing rules; the title or the name of the figure should be put under the figure, should be written from the left to the right and should be given a single space from the figure. If the name consists of more than one line, the researcher can provide a single space between the lines. The example for this explanation might be seen in Figure 1.

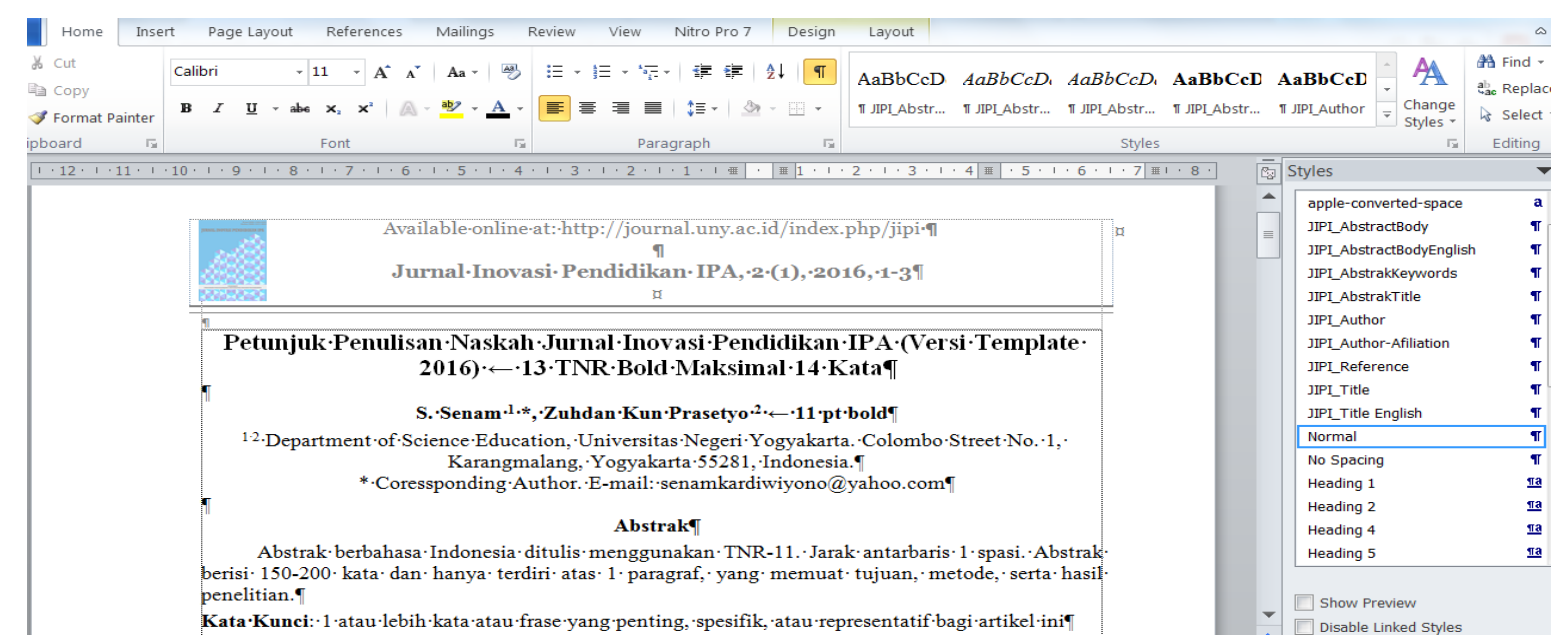

Figure 1. Displaying the Style in the Template 


\section{Jurnal Inovasi Pendidikan IPA, 2 (1), 2016 - viii}

S. Senam, Zuhdan Kun Prasetyo

The discussions should be focused to the association between the data and the results of analysis or the association between objectives of the study and the wider theoretical context. The discussions might also deal with the answers toward the questions of why such facts had been found in the data.

The discussions should be written closely to the data that had been discussed. The discussions should not be written separately from the data under discussion.

\section{CONCLUSIONS}

The conclusions might be some sort of generalization toward the findings in accordance with the problems of the study. The conclusions, on the other hand, might also be the recommendations for the further steps or stages.

\section{REFERENCES}

The composition of the list of references should follow the standard techniques and should be performed under the standardized and consistent manner. In order to maintain the consistency of reference and quotation manner, the list of references should make use of Reference Manager Applications such as Zotero, Mendeley or the paid applications. The list of references should be typed in the single space and there should be a single space-distance from one list of reference to another. An example for this explanation might be seen in the following example.
Gronlund, N.E. \& Linn, R.L. (1990). Measurement and evaluation in teaching. $\left(6^{\text {th }}\right.$ ed.). New York: Macmillan.

Effendi, S. (1982). Unsur-unsur penelitian ilmiah. Dalam Masri Singarimbun (Ed.). Metode penelitian survei. Jakarta: LP3ES.

Daniel, W.W. (1980). Statistika nonparametrik terapan. (Terjemahan Tri Kuntjoro). Jakarta: Gramedia.

Suyanto, S (2009). Keberhasilan sekolah dalam ujian nasional ditinjau dari organisasi belajar. Disertasi, tidak dipublikasikan. Universitas Negeri Jakarta.

Pritchard, P.E. (1992). Studies on the breadimproving mechanism of fungal alphaamylase. Journal of Biological Education, 26 (1), 14-17.

Retnawati, H. (2014). Teori respon butir dan penerapannya. Yogyakarta: Nuha Medika.

Rukmana, T., \& Mundilarto, M. (2016). Keterlaksanaan penilaian autentik mata pelajaran fisika SMA negeri. Jurnal Inovasi Pendidikan IPA, 2(1), 111-121. doi:http://dx.doi.org/10.21831/jipi.v2i1.83 82

\section{PROFILE}

This section contains the narrative text of birth, education from the last degree that contains the study program, the year of graduation and the recent employment/activity. 


\section{AUTHOR GUIDELINES}

1. Manuscript accepted is written in standard English Language or Indonesian language

2. The length of the manuscript is approximately 15 pages (or approximately 7000 words), written in Times New Roman 11, A4 paper format, margins: top 3; left 3; right 2; bottom 2, two columns (except for abstract, figure or table whose size cannot be reduced due to its readability), justified, single-spaced.

3. Manuscript comprises five main headings: Pendahuluan (Introduction); Metode (Method); Hasil dan Pembahasan (Findings and Discussion); Simpulan (Conclusions); Daftar Pustaka (References).

4. The title of the manuscript must be as brief as possible, and must represent the content of the manuscript.

5. Authors' names are written below the tittle, followed by authors' affiliation (name of the affiliation, address, postal code, and country) and e-mail address.

6. Abstract is written in two languages: Indonesian and English or only in English if the fulltext is written in English, as a representation of the manuscript. The abstract should not exceed 250 words for each language format, written narratively comprising aims/objectives, method, and findings of the research/article, in one paragraph.

7. Keywords: words or phrases which are important, specific, or representative to the article.

8. APA style is used as a reference in citation, references, and writing format.

9. The references of the article are in the form of journals and non-journals which are published in the last 10 years.

10. The manuscript should be written in the following TEMPLATE.

11. The manuscript must be in Microsoft Word (.doc/ .docx or .rtf), and sent to the journal system via online submission by creating account in this Open Journal System (OJS) [click REGISTER if you have not had any account yet; or click LOG IN if you have already had an account].

12. All Author(s)' names and identity(es) must be completely embedded in the form filled in by the corresponding author: email; affiliation; and each author's short biography (in the column of 'Bio Statement'). [if the manuscript is written by two or more authors, please click 'Add Author' in the 3rd step of 'ENTER METADATA' in the submission process and then enter each author's data.]

13. Authors' biography (in the column of Bio Statement) is written in the form of narration, including author's full name, place and date of birth, educational qualification/information started from bachelor degree (S-1) until the latest educational degree, the affiliation in which the author is currently working, phone number, and email address.

14. All correspondences, information and decisions for the submitted manuscripts are conducted through email written in the manuscript and/or the emails used for the submission. The status of the manuscript can be checked in the OJS by logging in to the journal.

15. If you have submission queries, please contact jipi.ppsuny@uny.ac.id / jipi.ppsuny@gmail.com 